\title{
КОМПОНЕНТНЫЙ СОСТАВ ЛЕТУЧИХ СОЕДИНЕНИЙ ХВОЙНЫХ В УСЛОВИЯХ СРЕДНЕЙ СИБИРИ
}

\author{
() В.А. Сенашова" ${ }^{* 1}$ А.А. Анискина ${ }^{1}$, М.А. Плячечник ${ }^{1}$, Т.В. Костякова ${ }^{2}$ \\ ${ }^{1}$ Институт леса им. В.Н. Сукачева СО РАН, Академгородок, 50/28, \\ Красноярск, 660036 (Россия), e-mail: vera0612@mail.ru \\ ${ }^{2}$ Хакасский технический институт - фрилиал Сибирского федерального \\ университета, ул. Щетинкина, 27, Абакан, Республика Хакасия, 655017 \\ (Россия)
}

Методом хромато-масс-спектрометрии установлены состав и массовая доля компонентов летучих соединений, выделяемых хвоей сосны обыкновенной (Pinus sylvestris L.), сосны сибирской (P. sibirica (Du Tour)), ели сибирской (Picea obovata Ldb.), можжевельника обыкновенного (Juniperus communis L.), можжевельника казацкого (J. sabina L.) в течение вегетационного периода. Всего в ходе работы идентифицировано 223 вещества. Выявлены как общие соединения для всех исследуемых растений, так и видоспецифичные.

Ключевые слова: хромато-масс-спектрометрия, летучие соединения, Pinus sylvestris L., P. sibirica (Du Tour), Picea obovata Ldb., Juniperus communis L., J. sabina L.,

\section{Введение}

Эпифитное микробное сообщество является неотъемлемой частью внешней среды, с которой взаимодействуют растения. Большинство эпифитных микроорганизмов питается выделениями растительных клеток, не внедряясь в ткани растения и не причиняя вреда растительному организму, и в свою очередь, выступают активными продуцентами ростовых веществ, фиксаторами атмосферного азота, биоредуцентами аэрозольных загрязнителей. Кроме того, эпифиты нередко играют защитную роль, препятствуя развитию попадающих на поверхность растения фитопатогенных грибов $[1,2]$. Микробное сообщество, ассоциированное с надземными органами растений, разнообразно по составу и объединяет представителей различных систематических групп микроорганизмов: бактерий, актиномицетов, дрожжевых и гифальных грибов [3, 4].

В нормальных условиях роста, не приводящих к ослаблению растения, обеспечиваются устойчивые

Сенашова Вера Александровна - младший научный сотрудник отдела физико-химической биологии и биотехнологии древесных растений, кандидат биологических наук, тел.: (391) 249-44 69, e-mail: vera0612@mail.ru

Анискина Антонина Александровна - научный сотрудник отдела физико-химической биологии и биотехнологии древесных растений, тел.: (391) 249-44 69, e-mail aniskina_a@ksc.krasn.ru Пляшечник Мария Анатольевна - младший научный сотрудник отдела физико-химической биологии и биотехнологии древесных растений, тел.: (391) 249-44 69, e-mail: lilwood@ksc.krasn.ru Костякова Татьяна Валерьевна - младший научный сотрудник научно-образовательной лаборатории «Биогеохимия экосистем Евразии», тел.: (3902) 22-70-64, e-mail: Tanya280111@ mail.ru взаимоотношения между растением-хозяином и населяющими его микроорганизмами. Численность и видовой состав эпифитов на поверхности растений изменяются во времени. На формирование и динамику эпифитного сообщества, помимо погодноклиматических факторов, определяющих ключевые экологические параметры среды, такие как температура, влажность, интенсивность солнечной радиации и т.п., важную роль играют летучие соединения, выделяемые поверхностью листовой пластинки [5]. Некоторые из этих веществ обладают бактериостатическими и даже бактерицидными свойствами, а другие могут использоваться эпифитами как источники дополнительного питания [6, 7]. Известно, что каждый

\footnotetext{
*Автор, с которым следует вести переписку.
} 
вид растений обладает характерным сообществом эпифитных микроорганизмов, несмотря на одинаковые экологические условия произрастания [8], что обусловливается различиями в составе экзаметаболитов, производимых листовым аппаратом.

В большинстве случаев образцы для исследования эфирных масел и летучих веществ собирают в конце вегетационного периода, когда стабилизируется их состав [9-11]. Для лучшего понимания процесса формирования эпифитного микробоценоза филлосферы необходим более частый отбор образцов.

Исходя из вышеизложенного, цель данной работы - изучить в течение вегетационного периода компонентный состав летучих соединений хвои древесных растений, широко распространенных в условиях Сибири.

\section{Экспериментальная часть}

Работа проводилась на территории стационара Института леса имени В.Н. Сукачева СО РАН «Погорельский бор» и в лабораторных условиях отдела физико-химической биологии и биотехнологии древесных растений на приборах Центра коллективного пользования Красноярского научного центра СО РАН.

Урочище «Погорельский бор» (1400 га) входит в Красноярскую островную лесостепь, расположенную по левобережью Енисея к северу от Красноярска. Современный рельеф северной левобережной части Енисея представлен полого-увалистой предгорной равниной. Макрорельеф Погорельского стационара это водораздел со слабозаметными уклонами в северном и южном направлениях (2-3을 наивысшая абсолютная отметка - 280 м). Абсолютные высоты колеблются в пределах 250-300 м. Мезорельеф представлен в виде ложбин и повышений. Климат — резко континентальный, умеренно-прохладный, среднегодовая температура $+1,7^{\circ} \mathrm{C}$. Среднегодовое количество осадков 470 мм, с колебанием в отдельные годы $320-630$ мм [12]. Бор является условно чистым насаждением, расположенным вне зоны загрязнения газообразными и пылевыми выбросами города Красноярска [13]. В таблице 1 приведены метеорологические показатели в районе исследования (использованы данные Красноярской метеорологической службы).

Материалом для исследований служила хвоя следующих растений: сосны обыкновенной (Pinus sylvestris L.), сосны сибирской (P. sibirica (Du Tour)), ели сибирской (Picea obovata Ldb.), можжевельника обыкновенного (Juniperus communis L.), можжевельника казацкого (J. sabina L.). Работа была приурочена к фенологическим фазам роста и развития хвойных [14-17]. Для каждого вида исследуемых растений было выбрано по пять деревьев (кустарников), с которых собирали хвою второго года жизни по 2 г без видимых повреждений. Сбор образцов осуществляли во вторую декаду мая, первую декаду июня и во вторые декады июля, августа и сентября 2011 г. Хвоинки измельчали, быстро помещали в виалы «Agilent», емкостью 20 мл, и заливали 5 мл пентана. После чего виалы герметично закрывали и в термосе со льдом транспортировали в лабораторию. Качественное определение компонентного состава образцов выполняли на хроматомасс-спектрометре «Agilent 5975С-7890A» фирмы Agilent (США) с использованием автоматического пробоотборника для жидких образцов Agilent 7683. Применяли 30-метровую кварцевую колонку НР-5 (сополимер 5\%-дифенил-95\%-диметилсилоксан) с внутренним диаметром 0,25 мм. Газ-носитель - гелий с постоянным потоком 1,1 мл/мин. Программирование температуры термостата: начальная температура $50{ }^{\circ} \mathrm{C}$ с последующим подъемом температуры до $200{ }^{\circ} \mathrm{C}$ со скоростью $4{ }^{\circ} \mathrm{C} / \mathrm{Mин,} \mathrm{затем} \mathrm{подъем} \mathrm{температуры} \mathrm{до}$ $280{ }^{\circ} \mathrm{C}$ (скорость подъема $20^{\circ} \mathrm{C} /$ мин), при достижении $280{ }^{\circ} \mathrm{C}$ выдержка в течение 5 мин. Объем вводимой

Таблица 1. Метеорологические показатели на территории стационара «Погорельский бор» $(2011$ г.)

\begin{tabular}{c|c|c|c}
\hline Месяц & $\begin{array}{c}\text { Средняя } \\
\text { температура } \\
\text { воздуха, } \mathrm{t}{ }^{\circ} \mathrm{C}\end{array}$ & $\begin{array}{c}\text { Относительная } \\
\text { влажность } \\
\text { воздуха, \% }\end{array}$ & $\begin{array}{c}\text { Количество } \\
\text { осадков за } \\
\text { месяц, мм }\end{array}$ \\
\hline Май & 10,03 & 64,61 & 68,5 \\
Июнь & 18,94 & 70,50 & 564 \\
Июль & 16,38 & 78,03 & 99,7 \\
Август & 15,2 & 80,45 & 98,7 \\
Сентябрь & 7,87 & 73,77 & 14,5 \\
\hline
\end{tabular}
пробы 0,2 мкл.

Температура испарителя $280^{\circ} \mathrm{C}$, температура ионизационной камеры $170{ }^{\circ} \mathrm{C}$, энергия ионизации 70 эВ.

Полученные хроматографические профили сравнивали по характерным органическим соединениям, идентифицированным при помощи библиотеки масс-спектров «NIST05a».

Статистическую обработку данных проводили в программе Microsoft Excel 2007. 


\section{Обсуждение результатов}

В результате исследований было идентифицировано порядка 53-93\% индивидуальных соединений от их общего числа. Примеры полученных хроматограмм приводятся на рисунке 1. Анализ выявленных соединений показал, что в пробах растительного материала, независимо от исследуемого вида растения, присутствуют вещества различных химических классов, основными из которых являются углеводороды (алканы, алкены, циклические и полициклические соединения), органические кислоты и их эфиры, спирты, производные фенола, фенантрена, нафталина. В пробах за период исследования выявлено 26 монотерпенов, 8 дитерпенов, 64 сесквитерпена, 9 алканов, 19 сесквитерпеновых, 8 дитерпеновых и 19 монотерпеновых спиртов, 19 эфиров, 6 кетонов, 2 дитерпеновых кислоты, 1 углеводород фенантренового ряда и 1 насыщенный углеводород (цетан ациклический). Всего в ходе работы идентифицировано 223 вещества.

Общими компонентами для всех исследованных растений являются семь монотерпенов, три сесквитерпена, дитерпеновый и сесквитерпеновый спирты, по одному эфиру, алкану и витамину Е (табл. 2). Причем некоторые из этих соединений присутствовали на протяжении всех месяцев исследований (например, терпинолен, $\beta$-мирцен), другие, в зависимости от вида растения, в отдельные месяцы. Например, $\tau$ терпинен присутствовал у ели и сосны сибирской только в начале вегетационного периода (в мае и июне соответственно) (табл. 3).

Для большинства исследуемых растений $\alpha$-пинен являлся доминирующим веществом либо содоминирующим. У можжевельника обыкновенного доля $\alpha$-пинена в пробе составляла 13,69-35,67\%, у сосны сибирской его доля достигала $27,8 \%$ (рис. 2). Считается, что этот монотерпен играет важную роль в защитной реакции растения на стрессовое воздействие [18].

Обращает на себя внимание динамика $\alpha$-фелландрена, общая для представителей изученных растений, относящихся к одному роду. Так, у обоих видов можжевельника $\alpha$-фелландрен отсутствовал в августе, а у сосны обыкновенной и сосны сибирской — в июле и августе. У ели сибирской в отличие от перечисленных видов растений данный монотерпен присутствовал в пробе на протяжении всего вегетационного периода (рис. 3). В то же время в динамике его изомера $\beta$-фелландрена подобной закономерности не выявлено. У сосны сибирской он обнаруживался в следовых количествах, у можжевельника обыкновенного - только в мае $(0,13 \%)$. У можжевельника казацкого и сосны обыкновенной $\beta$-фелландрен присутствовал с мая по сентябрь включительно. Причем процентное его количество в пробе у можжевельника казацкого было достаточно высоким: от 14,56 \% (сентябрь) до 17,27 \% (май). У сосны обыкновенной максимальная доля выявлялась также в мае $(2,76 \%)$, а минимальная — в июне $(0,05 \%)$. У ели $\beta$-фелландрен не обнаружен.

Количество соединений, синтезируемых растениями в различные фенологические фазы, неодинаково. Для представителей рода Pinus оно максимально в начале вегетации, а для рода Juniperus - в фенофазу активного роста (табл. 4).

Изучение компонентного состава летучих соединений хвои исследуемых растений показало, что каждый из видов обладает набором видоспецифичных веществ. Причем общая доля таких соединений в пробе может достигать 44,9\% (можжевельник обыкновенный) либо играть незначительную роль: 2,58\% (сосна обыкновенная). Ниже приводится более подробный анализ индивидуальных соединений.

В течение вегетационного периода у сосны сибирской выявлено 14 веществ, не обнаруженных у других изученных растений. Наибольшее их количество в пробе отмечено во второй половине вегетационного периода и достигает максимального значения в сентябре $(7,71 \%)$. Причем наибольший вклад составляют гермакрен В и метилламбертианат (табл. 5).

Таблица 2. Соединения, общие для хвои Pinus sylvestris L., Picea obovata Ldb., Pinus sibirica (Du Tour), Juniperus sabina L., Juniperus communis L.

\begin{tabular}{c|c|c}
\hline \multicolumn{2}{c|}{ Класс соединения } & Наименование компонента \\
\hline \multirow{2}{*}{ Терпены } & $\begin{array}{c}\text { монотерпены } \\
\text { сесквитерпены }\end{array}$ & $\begin{array}{c}\alpha \text {-пинен, } \beta \text {-пинен, } \beta \text {-мирцен, } \alpha \text {-фелландрен, } \tau \text {-терпинен, терпинолен, аллооцимен } \\
\delta \text {-кадинен, } \tau \text {-кадинен, копаен }\end{array}$ \\
\hline \multirow{2}{*}{ Спирты } & $\begin{array}{c}\text { дитерпеновый } \\
\text { сесквитерпеновый }\end{array}$ & фитол \\
& Эфиры & кариофиллен оксид \\
\hline \multicolumn{2}{c|}{ Алканы } & борнилацетат \\
Производные фенола & эйкозан \\
\hline
\end{tabular}



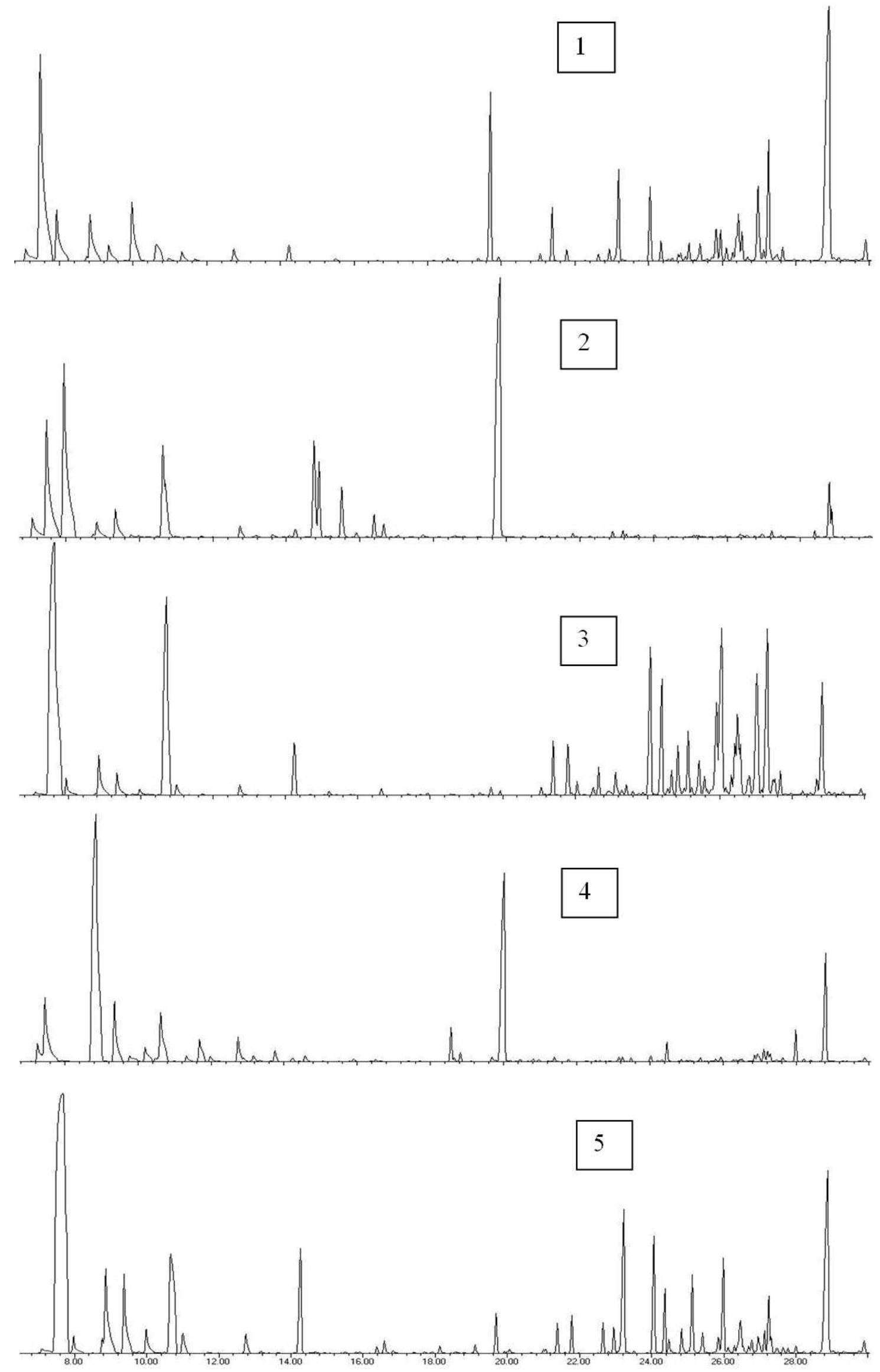

Рис. 1. Хроматограммы летучих соединений: 1 - Pinus sylvestris L., 2 - Picea obovata Ldb., 3 - Pinus sibirica (Du Tour), 4 - Juniperus sabina L., 5 - Juniperus communis L. 
Таблица 3. Встречаемость веществ, общих для Pinus sylvestris L., Picea obovata Ldb., Pinus sibirica (Du Tour), Juniperus sabina L., Juniperus communis L.

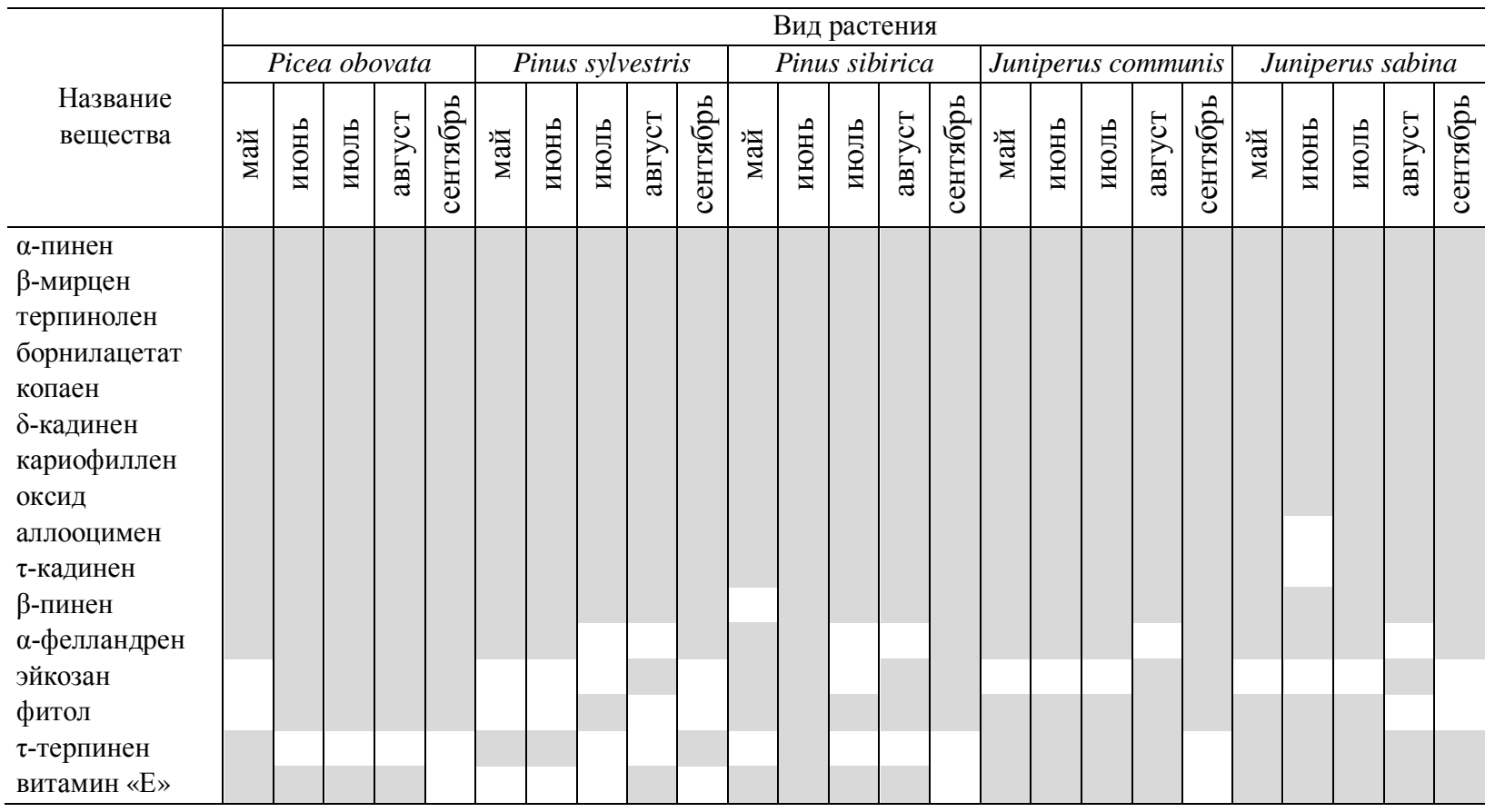

Таблица 4. Количество диагностированных веществ у исследуемых растений

\begin{tabular}{l|c|c|c|c|c|c}
\hline \multicolumn{1}{c|}{ Название растения } & Май & Июнь & Июль & Август & Сентябрь & Всего* \\
\hline Pinus sylvestris L. & 45 & 53 & 44 & 45 & 51 & 65 \\
Pinus sibirica & 56 & 47 & 51 & 47 & 42 & 66 \\
Picea obovata Ldb & 42 & 50 & 55 & 38 & 41 & 77 \\
Juniperus communis L. & 46 & 49 & 56 & 44 & 46 & 63 \\
Juniperus sabina L. & 38 & 39 & 44 & 43 & 41 & 56 \\
\hline
\end{tabular}

* За период с мая по сентябрь.

Таблица 5. Динамика летучих соединений, видоспецифичных для сосны сибирской (Pinus sibirica (Du Tour)), (количество в пробе, \%)*

\begin{tabular}{|c|c|c|c|c|c|c|}
\hline № & Название вещества & май & июнь & июль & август & сентябрь \\
\hline 1 & гермакрен В & 0,61 & 1,19 & 3,09 & 2,83 & 4,01 \\
\hline 2 & метилламбертианат & 1,81 & 1,86 & 2,06 & 2,66 & 2,53 \\
\hline 3 & $\alpha$-бисаболол & 0,47 & 0,46 & 0,38 & 0,28 & 0,29 \\
\hline 4 & 2-додеканон & 0,12 & 0,08 & 0,18 & 0,23 & 0,16 \\
\hline 5 & тунбергол & 0,12 & 0,1 & 0,16 & 0,12 & 0,18 \\
\hline 6 & иланген & 0,1 & 0,12 & 0,11 & 0,07 & 0,18 \\
\hline 7 & $\beta$-бурбонен & 0,05 & 0,1 & 0,12 & 0,1 & 0 \\
\hline 8 & юнипен & 0,07 & 0,09 & 0,05 & 0,05 & 0,11 \\
\hline 9 & $(10 S, 11 S)$-химачала-3(12),4-диен & 0,3 & - & 0,14 & - & - \\
\hline 10 & 2-деканон & 0,07 & 0,08 & 0,06 & 0,17 & 0,19 \\
\hline 11 & 2- тетрадеканон & 0,05 & 0,05 & 0,07 & 0,07 & 0,06 \\
\hline 12 & $E$-2-гексеналь & - & 0,06 & - & 0,07 & - \\
\hline 13 & метилнеоабиетат & 0,21 & - & - & - & - \\
\hline 14 & циклодецен & 0,07 & - & - & - & - \\
\hline & Всего & 4,07 & 4,29 & 6,43 & 6,66 & 7,71 \\
\hline
\end{tabular}

*Доля индивидуальных веществ выражена в процентах от общего содержания летучих соединений.

Из 65 идентифицированных летучих соединений сосны обыкновенной 51 встречалось у других хвойных, изученных нами. Обнаружено 13 веществ, выделяемых только хвоей сосны обыкновенной (табл. 6). Однако общая их доля не превышала 2,58\% от всего объема. Наиболее существенный вклад внесли сесквитерпены, в частности $\alpha$-кариофиллен.

У можжевельника обыкновенного обнаружено 15 видоспецифичных веществ (табл. 7). Причем суммарный их объем в пробе достигает $45 \%$ в середине сезона вегетации. Наибольший вклад вносит дитерпеновая дегидроабиетиновая кислота, ее доля колеблется в пределах 12,41-41,51\%. 

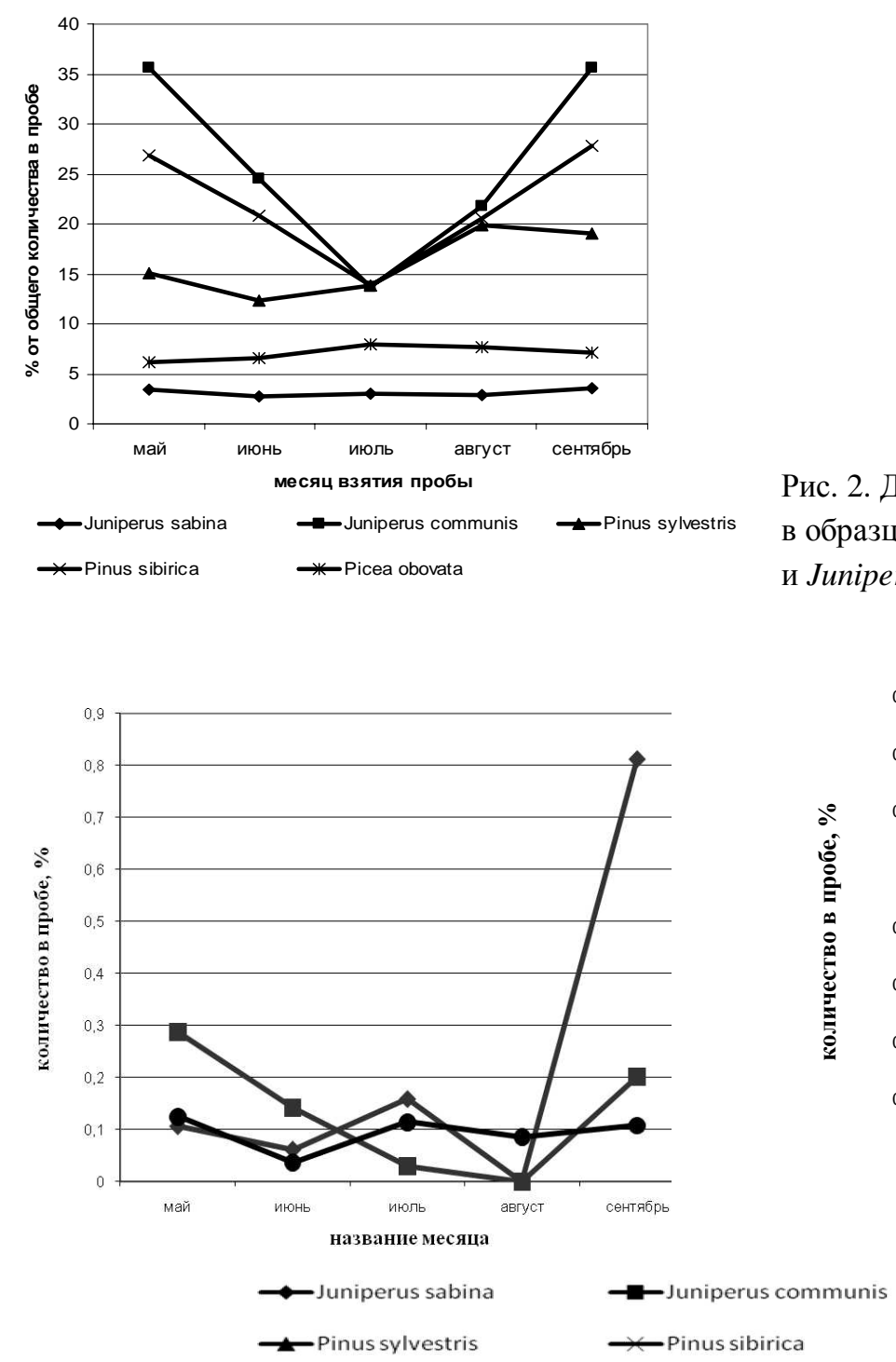

Рис. 2. Динамика встречаемости $\alpha$-пинена в образцах хвои Pinus spp., Picea obovata Ldb. и Juniperus spp. (2011 г.)

Рис. 3. Динамика встречаемости $\alpha$-фелландрена в образцах хвои Pinus spp., Picea obovata Ldb. и Juniperus spp. $(2011$ г.)

Таблица 6. Динамика летучих соединений, видоспецифичных для Pinus sylvestris L. (количество в пробе, \%)*

\begin{tabular}{|c|c|c|c|c|c|c|}
\hline № & Название вещества & май & июнь & июль & август & сентябрь \\
\hline 1 & $\alpha$-кариофиллен & - & 0,45 & 0,45 & 0,63 & 0,49 \\
\hline \multirow[t]{2}{*}{2} & 1,2,4a,5,6,8,-гексагидро-4,7-диметил-1-(1- & & & & & \\
\hline & метилэтил)-[1S-(1a,4ab,8aa)]-нафталин & 0,38 & 0,43 & 0,34 & 0,23 & 1,29 \\
\hline 3 & пачулен & 0,14 & 0,24 & 0,22 & - & 0,21 \\
\hline 4 & $\delta$-кадинол & 0,14 & 0,14 & 0,37 & 0,16 & 0,1 \\
\hline 5 & эремофиллен & 0,06 & 0,06 & 0,09 & - & - \\
\hline 6 & оксациклогептадекан-2-он & - & 0,09 & 0,15 & 0,11 & - \\
\hline 7 & $\alpha$-химачален & - & 0,09 & 0,09 & - & 0,1 \\
\hline 8 & гвайен & - & - & - & - & 0,28 \\
\hline 9 & 9-метил-с-октагидроантрацен & - & - & - & - & 0,11 \\
\hline 10 & генейкозан & - & - & - & 0,079 & 0 \\
\hline \multirow[t]{2}{*}{11} & 3-этенилдодекагидро-3,4a,7,7,10а-пентаметил-, & & & & & \\
\hline & [3R-(3a,4ab,6aa,10ab,10ba)]-1Н-нафто[2,1-b]пиран & - & 0,07 & - & - & - \\
\hline \multirow{3}{*}{$\begin{array}{l}12 \\
13\end{array}$} & 3,7,11,15-Тетраметил-2-гексадецен-1-ол & - & 0,06 & - & - & - \\
\hline & $(E, E)-7,11,15$-триметил-3-метилен-гексадека- & & & & & \\
\hline & 1,6,10,14-тетраен & - & 0,03 & - & - & - \\
\hline & Всего & 0,72 & 1,66 & 1,71 & 1,21 & 2,58 \\
\hline
\end{tabular}

* Доля индивидуальных веществ выражена в процентах от общего содержания летучих соединений. 
Из 77 идентифицированных летучих соединений ели сибирской 38 являются видоспецифичными. Их суммарный объем в пробе колеблется от 10,69 до 15,77\%. Наиболее существенную роль играют спирты, в частности камфора, доля которой увеличивается с мая по сентябрь от 1,35 до 7,94\% (рис. 4).

У можжевельника казацкого из 55 идентифицированных соединений 25 оказались видоспецифичными, среди которых доминирует эфир миртенилацетат (рис. 5). Его количество в пробе колеблется от 8 до 14,37\%. Максимальная доля видоспецифичных веществ в пробе отмечена в июне $(24,54 \%$ в пробе), а минимальная - в июле (16,41\% в пробе). Однако именно в июле количество видоспецифичных веществ у можжевельника казацкого максимально за сезон - 18.

Таблица 7. Динамика летучих соединений, видоспецифичных для Juniperus communis L. (количество в пробе, \%)*

\begin{tabular}{c|l|c|c|c|c|c}
\hline № & \multicolumn{1}{|c|}{ Название вещества } & Май & Июнь & Июль & Август & Сентябрь \\
\hline 1 & дегидроабиетиновая кислота & 18,96 & 32,14 & 41,51 & 37,86 & 12,41 \\
2 & кадина-3,9-диен & 1,7 & 1,26 & 0,91 & 0,67 & 2,38 \\
3 & ферругинол & 0,65 & 0,75 & - & 0,31 & 0,12 \\
4 & терпинилацетат & 0,43 & 0,21 & 0,34 & 0,56 & 0,55 \\
5 & биформен & 0,17 & 0,28 & 0,38 & 0,32 & 0,26 \\
6 & миртенол & 0,17 & 0,09 & 0,16 & 0,12 & 0,19 \\
7 & циннамальдегид & 0,16 & 0,07 & 0,1 & 0,1 & 0,12 \\
8 & пара-мент-1-ен-8-ол & - & 0,09 & 0,09 & 0,07 & - \\
9 & леден & - & 0,08 & 0,07 & 0,07 & 0,14 \\
10 & 4-гидрокси-2-метоксициннамальдегид & - & 0,06 & 0,06 & 0,09 & 0,1 \\
11 & сквален & - & - & 1,1 & 1,9 & 0,47 \\
12 & 7-ацетил-2-гидрокси-2-метил-5- & & & & \\
& изопропилбицикло[4.3.0]нонан & 0,11 & 0 & 0,05 & 0,07 & - \\
13 & циклопентадекан & 0,06 & 0,21 & 0 & - & - \\
14 & кубенол & - & - & 0,04 & - & - \\
15 & транс-неролидол & - & - & 0,03 & - & - \\
\hline \multicolumn{1}{r|}{ Всего } & 22,41 & 35,22 & 44,83 & 42,12 & 16,75 \\
\hline
\end{tabular}

* Доля индивидуальных веществ выражена в процентах от общего содержания летучих соединений

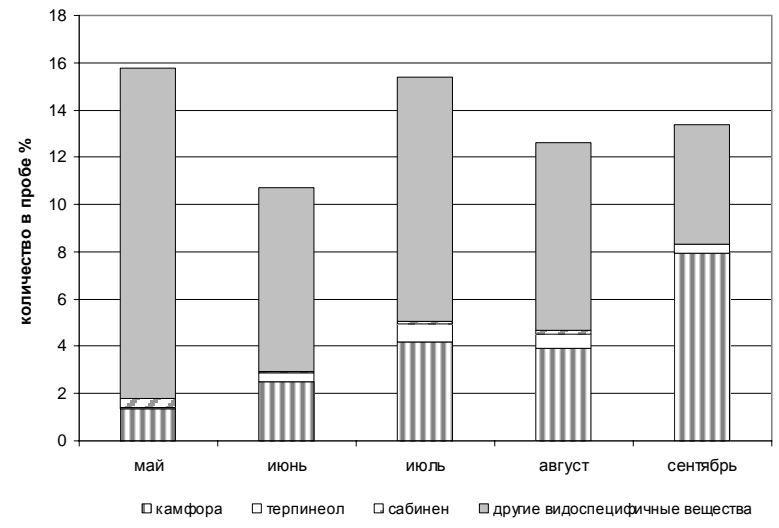

Рис. 4. Динамика видоспецифичных летучих соединений Picea obovata Ldb. (доля индивидуальных веществ выражена в процентах от общего содержания летучих соединений)

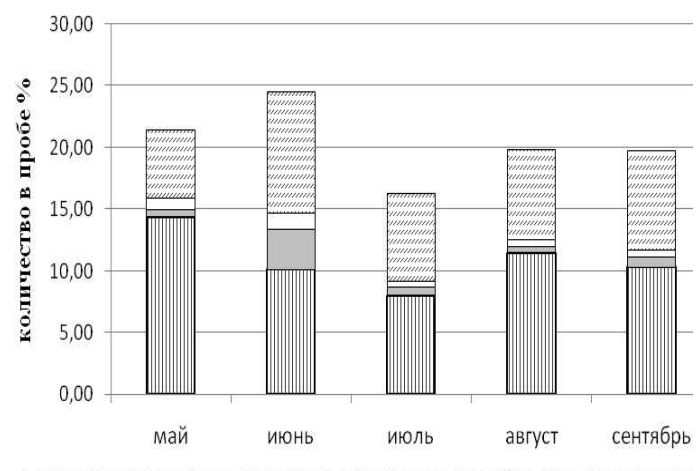

Фдругие видоспецифичные вещества 口октадекан 口а-түйен миртенилацетат

Рис. 5. Динамика видоспецифичных летучих соединений Juniperus sabina L. (доля индивидуальных веществ выражена в процентах от общего содержания летучих соединений)

\section{Bыводы}

Изучение компонентного состава летучих соединений хвойных в течение вегетационного периода показало, что каждый из изученных видов растений обладает характерным набором таких веществ. Наиболее разнообразный состав летучих соединений обнаружен у ели сибирской: за период исследований у нее диагностировано 77 веществ, а наименее - можжевельника казацкого (55 соединений). 
У всех исследованных растений обнаружены $\alpha$ - и $\beta$-пинен, $\beta$-мирцен, $\alpha$-фелландрен, $\tau$-терпинен, терпинолен, аллооцимен, $\delta$ - и $\tau$-кадинен, копаен, фитол, кариофиллен оксид, борнилацетат, эйкозан, витамин «Е» (токоферол).

В ходе эксперимента были идентифицированы летучие соединения, ассоциированные с конкретным видом изучаемых растений. Максимальное количество видоспецифичных веществ обнаружено у ели сибирской (38 соединений), а минимальное - у сосны обыкновенной (13). Причем в некоторых случаях их число в пробе достигает $44 \%$ от общего объема, как у можжевельника обыкновенного, или же является незначительным (доля видоспецифичных летучих соединений у сосны обыкновенной не превышает 2,58 \% от общего объема пробы). В то же время компонентный состав летучих соединений одного и того же вида растения зависит от условий произрастания. Соединения, выделяемые растением из одного географического региона, могут не обнаруживаться или не являться видоспецифичными для растения из другого региона. Например, в составе эфирного масла можжевельника обыкновенного, произрастающего на севере Ирана, выявлен гермакрен В [19], который в ходе наших исследований был идентифицирован только у сосны кедровой сибирской. И, наоборот, биформен, определенный нами как видоспецифичное вещество J. communis, не приводится в списке компонентов эфирного масла хвои и ягод можжевельника обыкновенного из Ирана.

\section{Список литературы}

1. Возняковская Ю.М. Микрофлора растений и урожай. Л., 1969. 240 с.

2. Гродницкая И.Д. Роль эпифитной микрофлоры в патогенезе сеянцев хвойных в питомниках : дисс. ... канд. биолог. наук. Красноярск, 1996. 216 с.

3. Сенашова В.А. Фитопатогенные микромицеты филлосферы хвойных насаждений Средней Сибири. Новосибирск, 2012. $104 \mathrm{c}$.

4. Добровольская Т.Г. Структура бактериальных сообществ почв. М., 2002. 282 с.

5. Сенашова В.А., Сорокин Н.Д. Влияние фитонцидной активности хвойных растений на эпифитные микроорганизмы в условиях Средней Сибири // Вестник КрасГАУ. 2011. №3. С. 93-97.

6. Саламатова Т.С., Зауралов О.А. Физиология выделения веществ растениями. Л., 1991. 152 с.

7. Сенашова В.А., Громовых Т.И., Сорокин Н.Д. Эпифитная микрофлора здоровой и пораженной хвои древесных пород Средней Сибири // Лесоведение. 2012. №4. С. 24-30.

8. Сенашова В.А. Эпифитное сообщество листового аппарата хвойных видов, пораженных заболеваниями типа «шютте» // Иммунопатология, аллергология, инфектология. 2010. №1. Паразитизм и симбиоз. Фитопатогенные и энтомопатогенные грибы. Микориза и лишайники. С. 128

9. Осмолевская Н.А., Паршикова В.Н., Степень Р.А. Влияние биоценотических и технологических факторов на выход и состав кедрового эфирного масла // Химия растительного сырья. 2001. №4. С. 97-102.

10. Чекушина Н.В., Шаталина Н.В., Ефремов А.А. Состав эфирного масла лиственницы сибирской // Химия растительного сырья. 2008. №3. С. 103-105.

11. Meier R.J., Goggans J.F. Heritabilities and correlations of the cortical monoterpenes of Virginia Pine (Pinus virginiana Mill.) // Silvae Genetica. 1978. Vol. 27, N2. Pp. 79-84.

12. Агроклиматический справочник по Красноярскому краю и Тувинской АО. Л., 1961. 168 с.

13. Скрипальщикова Л.Н., Грешилова Н.В. Уровни техногенных и рекреационных нагрузок на лесные фитоценозы пригородной зоны Красноярска // Актуальные проблемы лесного комплекса : сб. науч. тр. по итогам междунар. науч.-техн. конф. Вып. 21. Брянск, 2008. С. 125-128.

14. Елагин И.Н. Методика определения фенологических фаз у хвойных // Ботанический журнал. 1961. №7. C. 982-984.

15. Елагин И.Н. Сезонное развитие сосновых лесов. Новосибирск, 1976. 227 с.

16. Елагин И.Н., Лобанов А.И. Атлас-определитель фенологических фаз растений. М., 1979. 95 с.

17. Дистанционная индикация структуры таежных ландшафтов. Новосибирск, 1981. 246 с.

18. Фуксман И.Л. Влияние природных и антропогенных факторов на метаболизм веществ вторичного происхождения у древесных растений. Петрозаводск, 2002. 164 с.

19. Shahmir F., Ahmadi L., Mirza M., Korori S.A.A. Secretory elements of needles and berries of Juniperus communis L. ssp. communis and its volatile constituents // Flavour and fragrance journal. 2003. Vol. 18. Pp. 425-428.

Поступило в редакичию 25 февраля 2013 2. 
Senashova V.A. ${ }^{{ }^{*},}$, Aniskina A.A. ${ }^{l}$, Plyashechnik M.A. ${ }^{l}$, Kostyakova $T . V .{ }^{2}$ THE VOLATILE COMPOUND COMPOSITION OF CONIFEROUS TREES IN THE MIDDLE SIBERIA

${ }^{I}$ V.N. Sukachev Institute of Forest SB RAS, Akademgorodok, 50/28, Krasnoyarsk, 660036 (Russia),

e-mail:vera0612@mail.ru

${ }^{2}$ Khakassky Technical Institute - a branch of the Siberian Federal University, Shchetinkina st., 27, Abakan, Republic

of Khakassia, 655017 (Russia)

The composition and mass fraction of the components of the volatile compounds secreted by the needles of Pinus sylvestris L., P. sibirica (Du Tour), Picea obovata Ldb., Juniperus communis L., J. sabina L. during the growth season were studied by the chromate-mass-spectrometry method. In general, the work identified 223 substances. . The detected compounds were common for all the plants studied and some of them were associated with the certain species.

Keywords: chromate-mass-spectrometry, volatile compound, Pinus sylvestris L., P. sibirica (Du Tour), Picea obovata Ldb., Juniperus communis L., J. sabina L.

\section{References}

1. Vozniakovskaia Iu.M. Mikroflora rastenii i urozhai. [Microflora of plants and crops.]. Leningrad, 1969, 240 p. (in Russ.).

2. Grodnitskaia I.D. Rol' epifitnoi mikroflory v patogeneze seiantsev khvoinykh v pitomnikakh : diss. ... kand. biolog. nauk. [Role in the pathogenesis of epiphytic microflora of coniferous seedlings in nurseries: the dissertation Ph.D. in Biology]. Krasnoyarsk, 1996. 216 p. (in Russ.).

3. Senashova V.A. Fitopatogennye mikromitsety fillosfery khvoinykh nasazhdenii Srednei Sibiri. [Phytopathogenic fungi are phyllosphere conifer plantations in Central Siberia.]. Novosibirsk, 2012, 104 p. (in Russ.).

4. Dobrovol'skaia T.G. Struktura bakterial'nykh soobshchestv pochv. [The structure of soil bacterial communities.]. Moscow, 2002, 282 p. (in Russ.).

5. Senashova V.A., Sorokin N.D. Vestnik KrasGAU, 2011, no. 3, pp. 93-97. (in Russ.).

6. Salamatova T.S., Zauralov O.A. Fiziologiia vydeleniia veshchestv rasteniiami. [Physiology of plants release substances.]. Leningrad, 1991, 152 p. (in Russ.).

7. Senashova V.A., Gromovykh T.I., Sorokin N.D. Lesovedenie, 2012, no. 4, pp. 24-30. (in Russ.).

8. Senashova V.A. Immunopatologiia, allergologiia, infektologiia, 2010, no. 1, p. 128. (in Russ.).

9. Osmolevskaia N.A., Parshikova V.N., Stepen' R.A. Khimiia rastitel'nogo syr'ia, 2001, no. 4, pp. 97-102. (in Russ.).

10. Chekushina N.V., Shatalina N.V., Efremov A.A. Khimiia rastitel'nogo syr'ia, 2008, no. 3, pp. 103-105. (in Russ.).

11. Meier R.J., Goggans J.F. Silvae Genetica, 1978, vol. 27, no. 2, pp. 79-84.

12. Agroklimaticheskii spravochnik po Krasnoiarskomu kraiu i Tuvinskoi AO. [Agroclimaticale Directory in the Krasnoyarsk Territory and Tuva Autonomous Region.]. Leningrad, 1961, 168 p. (in Russ.).

13. Skripal'shchikova L.N., Greshilova N.V. Aktual'nye problemy lesnogo kompleksa: sb. nauch. tr. po itogam mezhdunar. nauch.-tekhn. konf. [Actual Problems of Forestry: collection of scientific papers on the results of international scientific and technical conference.]. Bryansk, 2008, no. 21, pp. 125-128. (in Russ.).

14. Elagin I.N. Botanicheskii zhurnal, 1961, no. 7, pp. 982-984. (in Russ.).

15. Elagin I.N. Sezonnoe razvitie sosnovykh lesov. [Seasonal development of pine forests.]. Novosibirsk, 1976, 227 p. (in Russ.).

16. Elagin I.N., Lobanov A.I. Atlas-opredelitel' fenologicheskikh faz rastenii. [Field guide phenological phases of plants.]. Moscow, 1979, 95 p. (in Russ.).

17. Distantsionnaia indikatsiia struktury taezhnykh landshaftov. [Remote indication of the structure of taiga landscapes.]. Novosibirsk, 1981, 246 p. (in Russ.).

18. Fuksman I.L. Vliianie prirodnykh i antropogennykh faktorov na metabolizm veshchestv vtorichnogo proiskhozhdeniia $u$ drevesnykh rastenii. [Influence of natural and anthropogenic factors on the metabolism of substances of secondary origin in woody plants.]. Petrozavodsk, 2002. 164 p. (in Russ.).

19. Shahmir F., Ahmadi L., Mirza M., Korori S.A.A. Flavour and fragrance journal, 2003, vol. 18, pp. 425-428.

Received February 25, 2013

Revised July 1, 2013

\footnotetext{
* Corresponding author.
} 
